\title{
LEGAL REQUIREMENTS FOR ADMISSION TO PUBLIC SCHOOLS
}

\author{
LeE O. GARBER*
}

The heart of our system of public education is the pupil. Therefore, it is particularly appropriate at this time, when education is claiming so much public attention, that consideration be given to the legal problems involved in the administration of pupil personnel. School administrators and boards of education, constantly faced with problems in this field, must look to the law for the answers. A not inconsequential number of these problems are concerned with the various aspects of admission requirements.

In considering the question of admission requirements, as they relate to individual pupils, it is well to recall that constitutional and statutory provisions pertaining to the question are decisive. When, however, their meanings are not clear and/or when pertinent questions are not covered by them, recourse must be had to decisional law. In this article an attempt will be made to discover, from court decisions, those legal principles which have a bearing upon such admission requirements as relate to age, health certificates, vaccination, tuition, and residence.

\section{I}

Any discussion of the question under consideration must, of necessity, be prefaced by a consideration of the legal nature of school attendance. Frequently, it is argued that a child has an inherent or absolute right to attend school at public expense. While courts sometimes speak of a child's "right" to attend schools, an analysis of their decisions leads to the conclusion that school attendance is not so much a right as a privilege or a duty imposed upon the child for the public good. ${ }^{2}$ Courts, in speaking of this right or privilege, quite consistently point out that it is not an inherent or absolute right, but rather one subject to such reasonable restrictions and regulations as the state sees fit to place upon it. ${ }^{3}$ In this connection, a Connecticut court, in considering the matter of school attendance, said: 4

- Associate Professor of Education, The School of Education, University of Pennsylvania.

${ }^{2}$ Piper v. Big Pine School District of Inyo County, I93 Cal. 664, 226 Pac. 926 (I924); Ward v. Flood, 48 Cal. 36, 17 Am. Rep. 405 (1874); People v. Stanley, 81 Colo. 276, 255 Pac. 610 (I927); Zavilla v. Masse, I 12 Colo. I83, I47 P.2d 823 (I944); Board of Education of Cleveland Heights v. State ex rel. Goldman, 47 Ohio App. 417, I9I N.E. 914 (1934).

${ }^{2}$ Bissell v. Davison, 65 Conn. 183, 32 Atl. 348 (1894); Scown v. Czarnecki, 264 Ill. 305 , 106 N.E. 276 (I914); Fogg v. Board of Education of Littleton, 76 N.H. 296, 82 Atl. x73 (I9I2); In re Walters, 84 Hun 457,32 N.Y. Supp. 322 (I895).

${ }^{3}$ Johnson v. Town of Deerfield, 25 F. Supp. 918 (D. Mass. 1939), aff'd, 306 U.S. 62I (I939); Piper v. Big Pine District of Inyo County, I93 Cal. 664, 226 Pac. 926 (1924); Ward v. Flood, 48 Cal. 36, I7 Am. Rep. 405 (1874); Bissell v. Davison, 65 Conn. 183, 32 Atl. 348 (I894); Barnard v. Inhabitants of Shelburne, 216 Mass. I9, I02 N.E. I095 (Igr3); Learock v. Putnam, IIx Mass. 499 (I873); Sherman v. Inhabitants of Charlestown, 62 Mass. (8 Cush.) 160 (r851); State v. Drew, 89 N.H. 54 , 192 Atl. 629 (1937); State v. Board of Education of City of Antigo, 169 Wis. 231, 172 N.W. I53 (1919).

Bissell v. Davison, 65 Conn. $183,190,32$ At. 348,349 (1894). 
This is a privilege or advantage, rather than a right, in the strict technical sense of the term. This privilege is granted, and is to be enjoyed, upon such terms and under such reasonable conditions and restrictions as the law-making power, within constitutional limits, may see fit to impose. ...

To somewhat the same effect is a Colorado decision which holds that "the right to attend the public schools is a civil right or privilege."5 In other words, it may be thought of as a right that "is not absolute and unqualified, but one to be enjoyed by all under reasonable conditions." "This right is subject to such restrictions as the state and as boards of education (under the authority granted them by statute) see fit to place upon it. It is, in other words, "subject to such reasonable regulations as to qualifications of pupils to be admitted and retained in the respective schools as the school committee shall prescribe."7

With reference to those reasonable rules that a school board may enact, the courts have identified certain general principles relating to school attendance. In the first place, they have held that school attendance is not a right, privilege, or immunity conferred upon one by virtue of his being a citizen of the United States-that admission cannot be demanded as the result of mere citizenship. This matter is, singularly, a state matter. ${ }^{8}$ Also, they have held that one living on lands, control over which has been ceded to the Federal Government, has no right to attend school, free of tuition, in the school district in which the lands are located ${ }^{9}$ and that children of parents employed by the Federal Government and living on Indian lands-an Indian reservation-are without authority to attend the public schools of the district of which the reservation is a part. ${ }^{10}$ On the other hand, it has been held that children living in a federal housing project owned by the United States government and operated in conjunction with a particular state, cooperating under its housing laws, are entitled to admission to the public schools of the district in which the housing project is located. ${ }^{11}$

In this same connection, it is quite universally agreed that the right or privilege of attending public schools is one that can be exercised only in the school district in which the child resides or has his domicile-that a school board, in the absence of statute, need not admit pupils from other school districts. In some states legislation has been enacted requiring school districts to admit non-resident pupils. The constitutionality of such legislation has been attacked on numerous occasions. Where the law requires the district of residence to pay tuition to the receiving district, there

¿Zavilla v. Masse, IIz Colo. 183, I88, I47 P.2d 823, 825 (I944).

${ }^{B}$ Sherman v. Inhabitants of Charlestown, 62 Mass. (8 Cush.) 160, 164 (1851).

${ }^{7}$ Barnard v. Inhabitants of Shelburne, 216 Mass. 19, 21, I02 N.E. 1095, I096 (1913).

${ }^{8}$ Piper v. Big Pine School District of Inyo County, I93 Cal. 664, 226 Pac. 926 (1924); Ward v. Flood, 48 Cal. 36, I7 Am. Rep. 405 (1874).

${ }^{\circ}$ Newcomb v. Inhabitants of Rockport, I83 Mass. 74, 66 N.E. 587 (1903); Opinions of Justiccs, I840, I Metc. 580 (Mass. I84I); Schwartz v. O'Hara Township School District, 375 Pa. 440, I00 A.2d 621 (1953).

${ }^{10}$ Rockwell v. Independent School District of Rapid City, 48 S.D. 137, 202 N.W. 478 (r925); School District No. 20 v. Steele, 46 S.D. 589 , I95 N.W. 448 (I923).

${ }^{11}$ McGwinn v. Board of Education of Cleveland City School District, 78 Ohio App. 405, 69 N.E.2d $38 x$ (1946), appeal dismissed, I47 Ohio St. 259, 70 N.E.2d 776 (1947). 
seems to be no question of its legality. Where it does not, however, the question is moot. One line of reasoning is to the effect that, education being a state function, a school district must educate all pupils that the state requires it to admit. ${ }^{12}$ There seems little reason to believe that a school district may not accept non-resident pupils, however, if it desires to do so. Where it does, whether voluntarily or under a statute requiring it to do so, it appears, according to the weight of authority, to have the right to charge a tuition fee..$^{13}$

While it is generally agreed that a school board may accept non-resident pupils, it should not, necessarily, be concluded that a board must pay the tuition of its own resident pupils who attend school in another district. In some states, under certain conditions, statutes require boards to pay the tuition of such pupils. But, in Arkansas, at least, where there is no statute governing this matter, it has been held that a district is without authority to pay the tuition of pupils in attendance elsewhere. ${ }^{14}$ Regardless of a school district's authority to impose a tuition fee for the education of non-resident pupils, or to pay the tuition of pupils in attendance elsewhere, it has been held that it cannot contract with another board in such a way as to impose upon the parents of non-resident pupils the duty of paying a matriculation fee. ${ }^{15}$ Also, in South Dakota, it has been held that a school board cannot discharge its obligation to maintain schools by paying to parents a sum of money in lieu of the cost of keeping the schools open. In this case, it should be noted, the board discontinued its schools, made arrangements for the proper schooling of all pupils (so desiring it) in other public schools, and made cash payments to parents desiring to send their children to sectarian schools. ${ }^{16}$

In connection with the question of the right of a board to admit pupils, it has been held that a board acted within its authority when it set up different entrance requirements for those who had not, previously, been enrolled in the system than for those who had. ${ }^{17}$ In so ruling, one court said: ${ }^{18}$

This would not mean, however, that the school board, in prescribing a rule that graduates of its own schools would be admitted without examination, while others who had graduated or finished courses elsewhere should pass a reasonable examination, had un-

${ }^{12}$ Ballou v. Kemp, 92 F.2d 556 (D.C. Cir. 1937); Cavanagh v. Ballou, 36 F. Supp. 445 (D.D.C. 194I); Wirth v. Corning, 75 F. Supp. 817 (D.D.C. 1948); Edwards v. State, I 43 Ind. 84,42 N.E. 525 (I895); Board of Education v. Board of Education, Io Ohio Cir. Ct. Rep. 617, 5 Ohio Dec. 96 (1895); In te Board of Education of Zanesville, 7 Ohio N.P. 564,5 Ohio S. \& C.P. Dec. 578 (I895); Edmondson v. Board of Education, Io8 Tenn. 557,69 S.W. 274 (1902).

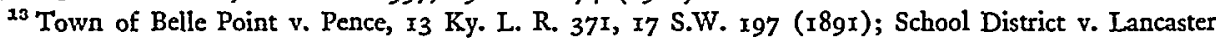
County, 60 Neb. I47, 82 N.W. 380 (1900); Todd v. Board of Education, 54 N.D. 235, 209 N.W. 369 (1926); City of Dallas v. Love, 23 S.W.2d, 43 I (Tex. Civ. App. 1930), aff'd, I20 Tex. 351, 40 S.W.2d 20 (193I).

1 Board of Education of Gould Special District v. Holdtoff, I7x Ark. 668, 285 S.W. 357 (I926).

${ }^{15}$ Peak v. Board of Education of Cuthbert, I77 Ga. 476, I70. S.E. 488 (r933).

${ }^{10}$ Hlebanja v. Brewe, 58 S.D. 35x, 236 N.W. 296 (I93I).

${ }^{17}$ Creyhon v. Board of Education of City of Parsons, 99 Kan. 824, I63 Pac. I45 (I9x7); Kayser v. Board of Education of City of St. Louis, 273 Mo. 643, 201 S.W. 53 I (I9r8). (1918).

${ }^{18}$ Kayser v. Board of Education of City of St. Louis, 273 Mo. 643, 653-654, 201 S.W. 53I, 533 
justly discriminated against the persons so required to pass such reasonable examination test.

As has been said, school attendance is not an absolute right of the child, but a matter subject to restrictions imposed by proper authorities. Concerning such restrictions, it is generally held that a school board may set up attendance areas and require individual pupils to attend particular schools as long as it acts reasonably and not in an arbitrary manner. In other words, it is a general rule that a pupil has no right to attend the school of his choice, within the district. ${ }^{10}$ In this connection, it has been held that a child cannot enforce a demand that he be admitted to the school nearest to his home. ${ }^{20}$ In commenting on this, a New York court held that the school nearest to a child's home is no more his than is the one most distant. ${ }^{21}$,

Likewise, it has been held that the authority of a school board to consolidate its schools is superior to a pupil's right to attend a particular school. Thus, if a board sees fit to close a particular school, a pupil may not complain on the ground that the closing of the school is an infringement of his right of attendance thereat. ${ }^{22}$ Needless to say, the action of the board must not be arbitrary nor unreasonable, and it must be in accord with statutes, if any govern this matter.

Again, in referring to the authority of the state to restrict the attendance of pupils, it has been held that the board, as the agent of the state, has the authority to classify and assign pupils in such manner as it deems appropriate to their general proficiency and welfare, as long as it acts reasonably. ${ }^{23}$ Thus, it has been held that a statute requiring the attendance of individual pupils suffering particular handicaps at

${ }^{10}$ Stephens v. Humphrey, r45 Ark. I72, 224 S.W. 442 (1920); Grove v. Board of School Inspectors, 20 Ill. 532 (1858); People v. Board of Education, 26 Ill. App. 476 (1888); People v. McFall, 26 Ill. App. 3 19 (1887); Steffey v. Sandifer, 202 Ill. App. 604 (1916); State v. Wirt, 203 Ind. 121, I77 N.E. 441 (193I); Webb v. School District No. 990, 167 Kan. 395, 206 P.2d 1066 (I949); Alford v. Board of Education of Campbell County, $298 \mathrm{Ky} .803,184$ S.W.2d 207 (1945); Reed v. Mason County Board of Education, 220 Ky. 489, 295 S.W. 436 (1927); Scott County Board of Education v. Crumbaugh, 213 Ky. 77I, 28I S.W. 977 (1926); Morse v. Ashley, I93 Mass. 294, 79 N.E. 48I (r906); In re Mycrs, II9 N.Y.S.2d 98 (Dom. Rel. Ct. I953); McEwan v. Broad, 9r N.Y.S.2d 565 (Sup. Ct. I949); Pcople v. Easton, I3 Abb. Pr. (N.s.) I59 (N.Y. 1872); State ex rel. Lewis v. Board of Education of Wilmington School District, 137 Ohio St. 145, 28 N.E.2d 491 (1940); Commonwealth v. School Directors, 4 Pa. Dist. Rep. 314 (1895); Cottrell v. School Board of Amity Township, 55 D. \& C. I19, 28 Erie I65 (Pa. I946).

${ }^{20}$ People v. Easton, 13 Abb. Pr. (N.s.) 159 (N.Y. I872); Commonwealth v. School Directors, 4 Pa. Dist. Rep. 314 (1895).

${ }^{21}$ People v. Easton, 13 Abb. Pr. (N.s.) 159 (N.Y. 1872).

22 Walker v. McKenzie, 209 Ga. 653, 74 S.E.2d 870 (1953); State ex rel. Ridge v. Johnson, III N.E.2d 803 (Ind. I953); Tufts v. State, Irg Ind. 232, 2 I N.E. 892 (1889); Potter v. District Township of Fredericksburg, 40 Iowa 369 ( 1875 ); Alford v. Board of Education of Campbell County, 298 Ky. 803, I84 S.W.2d 207 (1945); Morse v. Ashley, I93 Mass. 294, 79 N.E. 481 (1906); Ashton v. Jones, 47 Lack. Jur. 229 (Pa. 1947).

${ }^{23}$ Ward v. Flood, $48 \mathrm{Cal}$. 36, 17 Am. Rep. 405 (1874); Christman v. Board of Education of Consolidated Grade School, 347 Ill. App. 324, I06 N.E.2d 846 (1952); In re Petty, 241 Iowa 506, 4x N.W.2d 672 (1950); State v. Ghrist, 222 Iowa 1069, 270 N.W. 376 (1936), modified and rehearing denied, 222 Iowa 1069, 272 N.W. 440 (I937); Creyhon v. Board of Education of City of Parsons, 99 Kan. 824, I63 Pac. I45 (I917); Jones v. McProud, 62 Kan. 870, 64 Pac. 602 (rgor); Barnard v. Inhabitants of Shelburne, 216 Mass. I9, I02 N.E. I095 (1913); Board of Education of Cleveland Heights v. State ex rel. Goldman, 47 Ohio App. 417, 19I N.E. 914 (1934); Cottrell v. School Board of Amity Township, 55 D. \& C. 119,28 Erie 165 (Pa. 1946); State v. Board of Education of City of Antigo, 169 Wis. 23I, I72 N.W. I53 (1919). 
special schools set up for their education is constitutional. ${ }^{24}$ Likewise, it has been held that a board's rule requiring attendance at a special ungraded school of those pupils who had difficulty in doing the work required in the regular grades was a reasonable rule. ${ }^{25}$ One of the most interesting cases involving the question of the authority of a board to exclude a child from a regular school and to assign him to a particular school-a school for the deaf-was decided in Wisconsin some 35 years ago. ${ }^{2 B}$ In this case, a child who was crippled and physically defective, although apparently mentally normal, was assigned to a school for the deaf which the district maintained. He refused to attend this school and the parents upheld him. The boy was paralyzed and his physical and nervous make-up was affected. Today, such a child would probably be called a spastic. He was excitable and required an undue amount of his teacher's time. In an action by the parents to compel the board to admit him to his regular class and school, the court upheld the board and ruled that the rights of the individual pupil must be subordinated to the general welfare.

It should be noted, however, that this right of the board to classify and assign pupils has, in a few cases, been held to be restricted by the right of the parent to direct, within reasonable limits, his children's studies. ${ }^{27}$ In commenting on this matter, the Supreme Court of Colorado said: ${ }^{28}$

The right of the parents to select, within limits, what their children shall learn is one of the liberties guaranteed by the Fourteenth Amendment ... and of which . . . no state can deprive them.

In this same connection, it has been held that a pupil's right to school attendance is not such as to prevent a board from undertaking to reorganize the schools of the district. In other words, the authority of a school board to consolidate its schools and, when it deems it necessary, to abolish existing schools, is inherent in the board. ${ }^{29}$

\section{II}

At times the question arises as to what citizens, in terms of age groups, are eligible to attend free public schools. In answering this question, the courts, quite consistently, have held that constitutional provisions requiring the legislature to maintain a system of public schools open to all children between certain ages are not to be interpreted as limitations upon the power of the legislature, and that the legislature may provide school facilities for those outside these age limits, if it sees fit to do soi.e., it may provide for kindergartens, for institutions of higher education, and for schools for adults. The legislature must do that which is required, but it may go

24 In re Petty, 24I lowa 506, 4I N.W.2d 672 (ז950).

${ }^{25}$ State v. Ghrist, 222 Iowa 1069, 270 N.W. 376 (1936), modified and rehearing denied, 222 Iowa 1069, 272 N.W. 440 (1937).

${ }^{26}$ State v. Board of Education of City of Antigo, r69 Wis. 23I, I72 N.W. I53 (r9I9).

${ }^{27}$ Mo Hock Ke Lok Po v. Stainback, 74 F. Supp. 852 (D.C. Hawaii r947); People v. Stanley, 81 Colo. 276, 255 Pac. 6ro (r927); Trustees of Schools v. People, 87 Ill. 303, 29 Am. Rep. 55 (1877).

${ }^{28}$ People v. Stanley, 8r Colo. 276, 282, 255 Pac. 6ro, 6r3-6r4 (1927).

${ }^{20}$ State ex rel. Ridge v. Johnson, IrI N.E.2d 803 (Ind. r953); In re Myers, Irg N. Y. S.2d 98 (Dom. Rel. Ct. I953). 
beyond the constitutional mandate if it sees fit. A Colorado case is in point. ${ }^{30}$ When the Supreme Court was asked, by the House of Representatives, to rule on the question of the authority of the legislature to enact legislation to provide for the maintenance and support of kindergartens, in light of a constitutional provision requiring the legislature to establish a system of free public schools for all residents between the ages of 6 and 2r, it held that the legislature had the authority. To the same effect is a similar ruling by the Supreme Court of New Jersey. ${ }^{31}$ While the authority of the legislature to enact legislation relating to the question of age limits for school admission is quite clear, the question of the authority of school boards to pass rules and regulations restricting or qualifying a child's right to attend public schools is not so clear. It is generally held, however, that a board may pass any reasonable rule or regulation defining age limits within which a child may be admitted to public school, providing it is not in violation of a statute or constitutional provision. Frequently, such rules and regulations are questioned on the ground of reasonableness and also on the ground that they are violative of such provisions. In these cases, it becomes the duty of the court to resolve the issue in terms of the meaning of these provisions.

Some of these questions have involved school board rules setting the time at which a child may first enter the public schools. In Missouri, one section of the constitution provided that all persons between the ages of 6 and 20 should receive free instruction in the public schools. Another section provided that the public school fund should be faithfully appropriated for the establishment and maintenance of free public schools and for no other purpose. In interpreting these, the court ruled that expenditures by a board of education for the education of children under the age of 6 were prohibited by the constitution. It said: ${ }^{32}$ "The two sections, taken together, amount to both a requirement and a prohibition."

In Massachusetts, a rule of a school board to the effect that a child under the age of $\eta$ could not enter school except at the beginning of the fall term or within three or four weeks thereafter, unless he was qualified to enter classes at the time of his entry, was held to be a reasonable and enforceable rule. The court justified its ruling as follows: ${ }^{33}$

Children under 7 years of age, although allowed to attend the public schools, are not required to attend.... Grading is a permitted if not an essential feature of the public school system. The introduction to a school of a very young scholar late in the school year, if the scholar is not qualified to enter the existing classes, would tend strongly to impair the efficiency of the school, and so to prevent the other scholars from obtaining from it such advancement in learning and in training as would enable them to proceed with their education in due course.

In a somewhat similar case, an Illinois court held that a school board rule permitting children who had reached the age of 6 to enter school only at the beginning of

\footnotetext{
${ }^{30}$ In re Kindergarten Schools, 18 Colo. 234,32 Pac. 422 (1893).

${ }^{31}$ In re Newark School Board, 70 Atl. 881 (N.J. 1907).

${ }^{32}$ Roach v. Board of St. Louis Public Schools, 77 Mo. 484,488 (1883).

${ }^{33}$ Alvord v. Inhabitants of Town of Chester, I80 Mass. 20, 21, 6I N.E. 263, 264 (1901).
} 
the fall and spring terms was unreasonable. ${ }^{34}$ The statute made it the duty of the board to maintain schools for all children over the age of 6 and under the age of 2I. In this case an action was brought by a parent to compel the board to admit a child as soon as he attained the age of 6 , which was approximately $3^{\mathrm{I}}$ days after the beginning of the term. The court, in ruling for the parent, reasoned that because the rule caused the child to lose the benefits of free schooling for the remainder of the term, it was unreasonable.

In a Massachusetts case, the court held that a compulsory attendance law requiring parents to send those children to school who were between the ages of 8 and $\mathrm{I}_{4}$ was not to be interpreted as a definition of scholars of legal school age. As a result, it ruled that another law that provided that all children might attend public school subject to restrictions placed upon their attendance by law, was applicable to "all the residents of the commonwealth under the age of $2 \mathrm{I}$ years, as soon as they have sufficient capacity." ${ }^{35}$

Another aspect of this question of the authority of a school board to set age limits governing school attendance, concerns the rights of a board to deny admission to those in the upper-age levels. In this connection, a federal court has held that the word "pupils," as used in a federal law providing that pupils whose parents were employed in Washington, D. C. were entitled to attend school there, regardless of their place of residence, did not refer solely to those below college level and under the age of $2 x^{36}$ In this case, a girl whose father was employed in Washington, D. C. attended Wilson Teachers College. For several years she was admitted without tuition charge. Upon reaching the age of 2I, however, she was billed for tuition. In an action to enjoin the superintendent from dismissing this non-resident, it was contended that the law did not apply to those doing collegiate work and to those beyond the age of $2 \mathrm{r}$, on the ground that such pupils were emancipated. The court ruled differently, in terms of its interpretation of the intent of Congress.

Along somewhat the same line, a North Dakota court was asked to rule on the reasonableness of a school board rule requiring each pupil, with certain exceptions, to pay a tuition fee of $\$ 7.50$ for each half unit of credit earned after he had spent four years in high school attendance. When a boy failed to obtain enough credits to graduate in four years, and returned the fifth year, a board attempted to charge him tuition and justified its actions under the rule just mentioned. The court held the rule unreasonable in light of a constitutional requirement that the legislature provide a system of schools equally free, open, and accessible to all children between the ages of 6 and $2 \mathrm{r}^{37}$ In Wisconsin, on the other hand, it has been held that a school board was justified in charging tuition for an over-age pupil. ${ }^{38}$

\footnotetext{
st Board of Education v. Bolton, 85 Ill. App. 92 (189g).

${ }^{35}$ Inhabitants of Needham v. Inhabitants of Wellesley, 139 Mass. 372, 374, 3 I N.E. 732, 733 (I885).

${ }^{20}$ Cavanagh v. Ballou, 36 F. Supp. 445 (D.D.C. 194I).

${ }^{37}$ Batty v. Board of Education of City of Williston, 67 N.D. 6, 269 N.W. 49 (1936).

${ }^{88}$ Maxcy v. City of Oshkosh, I44 Wis. 238, I28 N.W. 899 (I910).
} 
III

As has been indicated, admission to public school is not an absolute right of the child but a privilege extended to him by the state. From this it follows that the state may, through the legislature or some other properly constituted authority such as a board of education, make rules or regulations excluding children from school if their presence is, in any way, a danger to the health of other children. ${ }^{30}$ As a result, it has been held that a school board may pass a rule requiring physical examinations and/or health certificates of all pupils under the pain of expulsion for those who refuse to comply. ${ }^{40}$ It may also spend public funds to hire doctors and nurses to make health inspections, ${ }^{41}$ but it may not use such funds to pay for the treatment of pupils. $^{42}$ In commenting on the authority of a school board to require physical examinations as a prerequisite to admission to public schools, a South Dakota court has said: $:^{43}$ ". . . a thing may be reasonable, though it conflicts with the individual views of the few, if it conforms to that of the many."

With regard to the authority of a state agency, a board of health, to exclude children from school when their presence endangers the health of others, it has been held that this authority extends to the exclusion of children who are not necessarily ill but who are suspected of being infected with some contagion. In North Dakota, it has been held that an order of the county board of health excluding children who were suspected of being afficted with trachoma from attending public school was reasonable. ${ }^{44}$ Similarly, in Minnesota, it has been held that a school board, in the exercise of general authority conferred upon it by a city charter, had the right to exclude pupils whose physical condition might endanger the health of others. ${ }^{45}$

\section{IV}

Courts have consistently held that statutes requiring compulsory vaccination are constitutional-that the passage of such acts is a legitimate exercise of the police power of the state. Such statutes may require the vaccination of all persons or they may authorize or require boards of education to set up a vaccination requirement as a prerequisite to school attendance, even in the absence of an epidemic. ${ }^{48}$ The consti-

${ }^{30}$ Hallett v. Post Printing and Publishing Co., 68 Colo. 573, 192 Pac. 658 (1920); Carr v. Inhabitants of Town of Dighton, 229 Mass. 304, II 8 N.E. 525 (19I8); Commonwealth v. Johnson, 309 Mass. 476, 35 N.E.2d 8or (r94x); Stone v. Probst, I65 Minn. 36r, 206 N.W. 642 (1925); Martin v. Craig, 42 N.D. 213, I73 N.W. 787 (I9r9); Crane v. School District No. 14 of Tillamook County, 95 Orc. 644, I88 Pac. 7r2 (I920).

to Hallett v. Post Printing and Publishing Co., 68 Colo. 573, I92 Pac. 658 (1920); Streich v. Board of Education of Independent School District of City of Aberdeen, 34 S.D. I69, 147 N.W. 779 (1914).

${ }^{11}$ See cases in note 40 supra, and also: State v. Brown, I12 Minn. 37o, 128 N.W. 294 (1910); City of Dallas v. Mosely, 286 S.W. 497 ('Tex. Civ. App. 1926).

12 Board of Education of City School District of Cleveland v. Ferguson, 68 Ohio App. 514,39 N.E.2d 196 (x94I); McGilvra v. Seattle School District No. I, Ir3 Wash. 619, I94 Pac. 817 (I92I).

${ }^{13}$ Streich v. Board of Education of Independent School District of City of Aberdeen, 34 S.D. $x 69,181$, 147 N.W. 779,783 (1914).

* Martin v. Craig, 42 N.D. 213, 173 N.W. 787 (rgrg).

"Stone v. Probst, 165 Minn. 361, 206 N.W. 642 (I925).

16 Jacobson v. Commonwealth of Massachusettts, I97 U.S. II (1905); Zucht v. King, 260 U.S. I74 (I922); Abeel v. Clark, 84 Cal. 226, 24 Pac. 383 (I890); French v. Davidson, I43 Cal. 658, 77 Pac. 663 (1904); State Board of Health v. Board of Trustees of Watsonville School District, 13 Cal. App. 
tutionality of such statutes has been attacked on numerous grounds, none of which have been held adequate. It has been held that the state, under the exercise of the police power, has the right to enact legislation designed to promote and protect the health and welfare of the people, as long as it acts reasonably and not in an arbitrary manner. ${ }^{47}$ Courts will not interfere with the discretion of the legislature, neither will they be concerned with its wisdom, in such matters. ${ }^{48}$

It has also been held that statutes concerning vaccination are neither unreasonable, arbitrary, nor discriminatory; that they do not deprive one of his rights without due process of law; ${ }^{49}$ and that they are not unconstitutional as class legislation. ${ }^{50}$

In this connection, a Pennsylvania court has held that a statute requiring vaccination is not unconstitutional on the ground that "it authorizes a trespass upon the reserved rights of the individual which are beyond the reach of even the police power." Instead, it ruled that such a statute "is not only a justifiable but a wise and beneficent exertion of the police power over the public health."52 Also, a New York court, in ruling such a statute was a proper exercise of the police power, pointed out that while the court recognized differences of opinion even among physicians as to the efficacy of vaccination, the legislature had the right to pass a law which, according to common belief, would result in preventing the spread of contagion be-

5I4, I 10 Pac. I37 (I910); Bissell v. Davison, 65 Conn. 183, 32 Atl. 348 ( 1894 ); Anderson v. State, 84 Ga. App. 259, 65 S.E.2d 848 (I95I); Morris v. City of Columbus, ro2 Ga. 792, 30 S.E. 850 (I898); Mosier v. Barren County Board of Health, 308 Ky. 829, 215 S.W.2d 967 (I948); Hammond v. Town of Hyde Park, 195 Mass. 29, 80 N.E. 650 (I907); Spofford v. Carlton, 238 Mass. 528, I3I N.E. 3x4 (I92I); Matthews v. Board of Education, I27 Mich. 530, 86 N.W. I036 (Ig0I); State v. Cole, 220 Mo. 697, Irg S.W. 424 (1909); Barber v. School Board of Rochester, 82 N.H. 426, 135 Atl. I59 (I926); Cram v. School Board of Manchester, 82 N.H. 495, I36 Atl. 263 (1927); State v. Drew, 89 N.H. 54, I92 Atl. 629 (1937); Sadlock v. Board of Education of Borough of Carlstadt, I37 N.J.L. 85, 58 A.2d 218 (1948); In re Walters, 84 Hun 457, 32 N.Y. Supp. 322 (1895); People v. Ekerold, 21 I N.Y. 386, I05 N.E. 670 (1914); Viemeister v. White, 88 App. Div. 44, 84 N.Y. Supp. 712 (2d Dep't r903), aff'd, I79 N.Y. 235,72 N.E. 97 (I904); State v. Hay, I26 N.C. I99, 35 S.E. 459 (1900); State v. Board of Education of Village of Barberton, 29 Ohio Cir. Ct. Rep. 375 (xg05), affd, 76 Ohio St. 297, 8I N.E. 568 (1907); State v. Board of Education of City of Cincinnati, 154 Ohio St. 469, 96 N.E.2d 413 (I95I); Field v. Robinson, I98 Pa. 638, 48 Atl. 873 (Igor); Stull v. Reber, 215 Pa. 156, 64 Atl. 4I9 (I906); Zucht v. King, 225 S.W. 267 (Tex. Civ. App. I920); State v. Shorrock, 55 Wash. 208, I04 Pac. 2I4 $(r 909)$.

${ }^{47}$ Abeel v. Clark, 84 Cal. 226, 24 Pac. 383 (1890); French v. Davidson, I43 Cal. 658, 77 Pac. 663 (1904); Morris v. City of Columbus, 102 Ga. 792, 30 S.E. 850 (1898); Sadlock v. Board of Education of Borough of Carlstadt, I37 N.J.L. 85, 58 A.2d 218 (r948); State v. Board of Education of Village of Barberton, 29 Ohio Cir. Ct. Rep. 375 (I905), aff'd, 76 Ohio St. 297, 8I N.E. 568 (1907); Stull v. Reber, 215 Pa. 156, 64 Atl. 419 (1906).

${ }^{t 8}$ State Board of Health v. Board of Trustees of Watsonville School District, 13 Cal. App. 514, IIo Pac. 137 (I9ro); Bissell v. Davison, 65 Conn. I83, 32 Atl. 348 (1894); Anderson v. State, 84 Ga. App. 259, 65 S.E.2d 848 (I95I); Cram v. School Board of Manchester, 82 N.H. 495, 136 Atl. 263 (I927); Sadlock v. Board of Education of Borough of Carlstadt, I37 N.J.L. 85, 58 A.2d 218 (1948).

${ }^{40}$ Jacobson v. Commonwealth of Massachusetts, I97 U.S. II (1905); Abeel v. Clark, 84 Cal. 226, 24 Pac. 383 ( 1890 ); Bissell v. Davison, 65 Conn. 183,32 Atl. 348 ( 1894 ); Cram v. School Board of Manchester, 82 N.H. 495, 136 Atl. 263 (r927); Viemeister v. White, 88 App. Div. 44, 84 N.Y. Supp. 712 (2d Dep't r903), aff'd, I79 N.Y. 235, 72 N.E. 97 (1904); Stull v. Reber, 215 Pa. 156, 64 Atl. 4Ig (rgo6); Staffel v. San Antonio School Board, 201 S.W. 413 (Tex. Civ. App. I9I8).

${ }^{00}$ French v. Davidson, 143 Cal. 658, 77 Pac. $66_{3}$ (I904).

E1 Stull v. Reber, 215 Pa. 156, I63, 64 Atl. 419, 421 (I906).

${ }^{52} \mathrm{Id}$. at I63, 64 Atl. at $42 \mathrm{I}$. 
cause "what the people believe is for the common welfare must be accepted as tending to promote the common welfare, whether it does in fact or not." 53

In many cases challenging the constitutionality of such statutes, it has been contended that they violate one's liberty of conscience and right of religious freedom. ${ }^{54}$ With these contentions, the courts are in consistent disagreement. Concerning this matter, a New Jersey court pointed out that "the constitutional guaranty of religious freedom was not intended to prohibit legislation with respect to the general public welfare."55 To the same effect is a New York decision in which the court ruled that the constitution makers "did not intend that the law would protect a person who might conceive of a God and the worship of that conception of God in a manner which might endanger the lives of the community in which such person might live."56 Similarly, in one of the most recent decisions of this type ${ }^{\text {t7 }}$ the court said : 58

... religious freedom embraces two conceptions, "Freedom to believe and freedom to act. The first is absolute but, in the nature of things, the second cannot be." . .

... the constitutional guarantee of religious freedom does not permit the practice of religious rights dangerous or detrimental to the lives, safety or health of the participants or to the public. ....

There may be no interference with appellant's ... religious belief against vaccination, but he may not endanger the health of the community by refusing to have his daughter vaccinated.

In a somewhat similar case, recently decided in Georgia, the court said: ${ }^{50}$

Liberty of conscience is one thing. License to endanger the lives of others by practices contrary to statutes passed for the public safety and in reliance upon modern medical knowledge is another. ... The opinion of the defendants that they should practice healing without the aid of medicine is not a legal justification for refusal to abide by the statutes of this state and regulations passed pursuant thereto, and for this reason freedom of worship was not an issue in the case.

With respect to the legality of such legislation, a California court has held that a compulsory attendance act passed subsequent to a compulsory vaccination act did not repeal the latter, on the ground that courts do not favor repeal by implication. ${ }^{00}$

Where the statute gives the school board the right to require vaccination of all

${ }^{53}$ Viemeister v. White, 179 N.Y. 235, 24I, 72 N.E. 97, 99 (I904).

s4 Anderson v. State, 84 Ga. App. 259, 65 S.E.2d 848 (I95I); Mosier v. Barren County Board of Health, $308 \mathrm{Ky} .829$, 2x5 S.W.2d 967 (1948); Commonwealth v. Green, 268 Mass. 585, x68 N.E. rox (1929); Sadlock v. Board of Education of Borough of Carlstadt, r37 N.J.L. 85, 58 A.2d 218 (1948); In re Whitmore, 47 N.Y.S.2d 143 (Dom. Rel. Ct. 1944); State ex rel. Dunham v. Board of Education of City School District of Cincinnati, 154 Ohio St. 469, 96 N.E.2d 4x3 (1951); Dunham v. Board of Education of City School District of Cincinnati, 98 N.E.2d 594 (Ohio 1950); Staffel v. San Antonio School Board, 20x S.W. 413 (Tex. Civ. App. 1918).

${ }^{6 \sigma}$ Sadlock v. Board of Education of Borough of Carstadt, r37 N.J.L. 85, 9I, 58 A.2d 218, 222 (1948).

${ }^{5}$ In re Whitmore, 47 N.Y.S.2d 143,146 (Dom. Rel. Ct. I944).

${ }^{67}$ Mosier v. Barren County Board of Health, 308 Ky. 829, 215 S.W.2d 967 (1948).

${ }^{58}$ Id. at 833,215 S.W.2d at 969 .

${ }^{50}$ Anderson v. State, 84 Ga. App. 259, 264, 65 S.E.2d 848, 852 (195I).

${ }^{\circ 0}$ State Board of Health v. Board of Trustees of Watsonville School District, 13 Cal. App. 514, 110 Pac. 137 (19ro). 
pupils who are physically fit, it has been held that, in the case of an epidemic, a school board may require that those excepted be vaccinated or excluded. In so holding, a Massachusetts court ruled that the statute "was not intended to take away from the school committee the power to make proper regulations for the protection of all the pupils, if the prevalence of smallpox seems to require special precautions." ${ }^{\prime 1}$

Where there is no statute requiring or permitting compulsory vaccination, the rule appears to be somewhat different. Then, so it is generally held, a school board has the right to pass a rule requiring vaccination as a condition precedent to attendance, but the right is dependent upon the existence of an epidemic or an emergency. ${ }^{62}$ However, the opposite has been held. ${ }^{63}$ Thus, a North Carolina court took the stand that a board had as much right to take action to prevent the occurrence of an epidemic as it had to halt the epidemic after it had once started. ${ }^{64}$ In support of the general rule that a school may require pupils to be vaccinated during the existence of an epidemic, on the pain of not being permitted to attend, a Pennsylvania court said: ${ }^{65}$

It would not be doubted that the directors would have the right to close the schools temporarily during the prevalence of any serious disease of an infectious or contagious character. This would be a refusal of admission to all the children of the district.... For the same reason they may exclude such children as decline to comply with requirements looking to prevention of the spread of contagion, provided these requirements are not positively unreasonable in their character.

An Illinois case held that a school board did not exceed its authority in requiring the vaccination of all pupils during an epidemic-that it was not required to limit the application of the rule solely to those who had been exposed. In so holding the court said:" "No child has a constitutional right to carry to others in school the loathsome disease of smallpox."

Sometimes boards of health, either state or local, or both, pass rules requiring vaccination as a condition precedent to school attendance. When such is the case; the situation becomes somewhat more complicated, particularly if the school board disapproves. Such a situation arose in Michigan during the school year rg22-23. The state board of health, in the exercise of its discretion, passed a resolution re-

01 Hammond v. Town of Hyde Park, I95 Mass. 29, 31-32, 80 N.E. 650, 65I (I907).

${ }^{62}$ Auten v. Board of Directors of Special School District of Little Rock, 83 Ark. 43I, 104 S.W. 130 (1907); Burroughs v. Mortenson, 312 Ill. I63, I 43 N.E. 457 (1924); People v. Board of Education, 234 Ill. 422,84 N.E. I046 (Ig08); Potts v. Breen, I67 Ill. 67, 47 N.E. 81 (I897); Osborn v. Russell; 64 Kan. 507, 68 Pac. 60 (r902); Mathews v. Board of Education of School District No. I, I27 Mich. 530, 86 N.W. 1036 (190I); Bright v. Beard, I32 Minn. 375, 157 N.W. 501 (1916); State v. Zimmerman, 86 Minn. 353, 90 N.W. 783 (1902); State ex rel O'Bannon v. Cole, 220 Mo. 697, Ixg S.W. 424 (xg09); Rhea v. Board of Education of Devils Lake Special School District, 4I N.D. 449, I7I N.W. I03 (I9I9); Dufficld v. School District of City of Williamsport, 162 Pa. St. 476, 29 Atl. 742 (1894); Glover v. Board of Education, I4 S.D. 139, 84 N.W. 761 (rgoo); Zucht v. San Antonio School Board, I70 S.W. 840 (Tex. Civ. App. 1914).

${ }^{\circ}$ In re Rebenack, 62 Mo. App. 8 (1895); Hutchins v. School Committee of Town of Durham, 137 N. C. 68,49 S.E. 46 (1904).

" Hutchins v. School Committee of Town of Durham, 137 N.C. 68, 49 S.E. 46 (r904).

${ }^{\circ t}$ Duffield v. Williamsport School District, I62 Pa. 476, 483, 29 At. 742 (I894).

${ }^{\circ}$ Hagler v. Larner, 284 Ill. 547, 552-553, I20 N.E. 575, 577 (r9r8). 
quiring all teachers, pupils, and janitors in the Lansing schools to be vaccinated or excluded from school. The local board of education passed a resolution reciting the fact there was no epidemic, as there were only $\mathrm{x} 7$ cases, and directed the admission of all, whether vaccinated or not. In a mandamus action the court required the enforcement of the board of health's order. It followed the line of reasoning, accepted by most courts, ${ }^{67}$ to the effect that a board of health (either state or local), while not expressly authorized so to do, may, under a general grant of authority, pass a rule or regulation requiring vaccination as a condition precedent to school attendance, but only when an epidemic exists. ${ }^{68}$ Concerning the rights of pupils or boards of education to complain of such regulations of boards of health, an Arkansas court said: ${ }^{99}$

It is true that the board of health is not authorized to manage or control the schools of the state, either public or private. That power is conferred upon other agencies. The prevention or spread of contagious or infectious diseases by preventing unvaccinated persons from associating with the school children and school teachers of the state in no way infringes upon the constitutional right to attend the schools or the management and control thereof by school boards or directors.

This authority of boards of health to require vaccination, under a general grant of power, has been denied in at least one case, ${ }^{70}$ in which it was held that the board had only those powers expressly granted to it, and that it had no legislative authority, such as would be essential to taking the action it did. In another case, an Illinois court held that a statute giving boards of health the authority to make rules and regulations to check the spread of disease, and giving them quarantine power, did not confer this authority on the Commissioner of Health in Chicago, which city had no board of health. ${ }^{71}$

Courts have frequently ruled that a board of education and a board of health have the authority to require vaccination on pain of exclusion; furthermore, it has been held that this authority is also vested in the city council and that an ordinance to this effect is legal. ${ }^{72}$

As has been indicated, this right of requiring vaccination, regardless of who exercises it, can only be exercised in case of the existence of an epidemic, in the absence

${ }^{\text {ot }}$ People v. Board of Education of City of Lansing, 224 Mich. 388, 400-40r, 195 N.W. 95, 99 (r923). - ${ }^{68}$ Seubold v. Fort Smith Special School District, 218 Ark. 560, 237 S.W.2d 884 (195r); State v. Martin, and Brazil v. State, I34 Ark. 420, 204 S.W. 622 (19r8); Hagler v. Larner, 284 Ill. 547, r20 N.E. 575 (1918); People v. Board of Education of City of Chicago, 234 Ill. 422, 84 N.E. 1046 (1908); School Directors v. Breen, 60 Ill. App. 201 (I895); Blue v. Beach, 155 Ind. 121, 56 N.E. 89 (1900); State v. Beil, 157 Ind. 26, 60 N.E. 672 (190I); Vonnegut v. Baun, 206 Ind. 172, 188 N.E. 677 (1934); Osborn v. Russell, 64 Kan. 507, 68 Pac. 6o (Ig02); Board of Trustees of Highland Park Graded Common School District v. McMurtry, I69 Ky. 457, r84 S.W. 390 (19r6); Mosier v. Barren County Board of Health, 308 Ky. 829, 215 S.W.2d 967 (1948); Crane v. School District No. I4 of Tillamook County, 95 Ore. 644, I88 Pac. 712 (r920); State v. Board of Education of Salt Lake City, 2I Utah 401, 60 Pac. ror3 (1900); State v. Partlow, Ir9 Wash. 316, 205 Pac. 420 (I922).

${ }^{60}$ State v. Martin, 134 Ark. 420, 425-426, 204 S.W. 622, 624 (1918).

${ }^{70}$ State v. Burdge, 95 Wis. 390,70 N.W. 347 (1897).

${ }^{21}$ Burroughs v. Mortenson, 312 Ill. 163 , I43 N.E. 457 (1924).

${ }^{72}$ City of New Braunfels v. Waldschmidt, rog Tex. 302, 207 S.W. 303 (1918); Zucht v. King, 225 S.W. 267 (Tex. Civ. App. I920). 
of a statute to the contrary. In defining what constitutes an epidemic, it will be found that courts differ. In Indiana, where the court held a board of health had the authority to compel vaccination, it was held the statute vested the board with jurisdiction to determine whether an epidemic did or did not exist. ${ }^{73}$ In Kentucky and Arkansas it has been held that a board of health that had the authority to compel vaccination of school children might use its discretion in determining when the need for such action threatened-that it need not wait until an epidemic existed, but could act to forestall a threatened epidemic. ${ }^{74}$ In Michigan it has been held that the existence of $I 7$ cases of smallpox in the city of Lansing was sufficient to constitute an epidemic. $^{75}$ In Minnesota, where one case of smallpox appeared among the students of a large high school, the court held that the board of health was authorized to make vaccination compulsory ${ }^{76}$ In another Michigan case, where smallpox existed throughout the state, but there were no cases in Kalamazoo, the court ruled there was no epidemic there, and that the Kalamazoo school board was without authority to pass a rule requiring vaccination. ${ }^{77}$ In Illinois it has been held that there is nothing in the nature of an emergency in the occasional recurrence of cases of smallpox, to warrant the passing of a rule requiring that all pupils be vaccinated..$^{78}$ In any case, when boards of education or boards of health find it necessary to pass rules requiring vaccination, such rules become ineffective once the emergency ceases to exist. $^{70}$

Another aspect of the problem of vaccination, as it relates to attendance, concerns the right of a school board, or of a board of health, to prescribe the method of vaccination. Concerning this matter, courts have consistently held that such boards have the authority-that they may adopt any reasonable rule or regulation to effect the purpose sought to be accomplished. As a result, courts have consistently held that a rule requiring inoculation with the virus of cowpox is reasonable. ${ }^{80}$ In this connection, a Missouri court has held that vaccination, by means of giving vaccine virus internally in the form of pills or tablets, did not meet the requirements of a board rule that required each pupil to present a certificate to the effect he had been vaccinated with vaccine virus. ${ }^{81}$ To the same general effect are court rulings in

${ }^{73}$ Vonnegut v. Baun, 206 Ind. 172, 188 N.E. 677 (1934).

"State v. Martin, I34 Ark. 420, 204 S.W. 622 (1918); School Directors v. Breen, 6o Ill. App. 2ór (1895); Board of Trustees of Highland Park Graded Common School District v. McMurtry, I69 Ky. 437, I 84 S.W. 390 (I9r6); Mosier v. Barren County Board of Health, 308 Ky. 829, 215 S.W.2d 967 (1948).

${ }_{75}$ People v. Board of Education of City of Lansing, 224 Mich. 388, x95 N.W. 95 (I923).

${ }^{70}$ Bright v. Beard, 132 Minn. 375, 157 N.W. $50 x$ (1916).

${ }^{77}$ Mathews v. Board of Education of School District No. I, I27 Mich. 530, 86 N.W. I036 (IgoI).

${ }^{78}$ People v. Board of Education of City of Chicago, 234 Ill. 422,84 N.E. ro $_{4} 6$ (1908).

${ }^{70}$ School Directors v. Breen, 60 Ill. App. 201 (I895); Blue v. Beach, I55 Ind. I2I, 56 N.E. 89 (1900); Zucht v. San Antonio School Board, r7o S.W. 840, (Tex. Civ. App. I9r4).

${ }_{80}$ Allen v. Ingolls, I82 Ark. 991, 33 S.W.2d I099 (I93I); State ex rel. O'Bannon v. Cole, 220 Mo. 697, 119 S.W. 424 (1909); Lee v. Marsh, 230 Pa. 351, 79 Atl. 564 (19rI); Abney v. Fox, 250 S.W. 2ro (Tex. Civ. App. 1923); MeSween v. Board of School Trustees of City of Ft. Worth, 6o Tex. Civ. App. 270,129 S.W. 206 (1910).

${ }^{81}$ State ex rel. O'Bannon v. Cole, 220 Mo. 697, II9 S.W. 424 (rgog). 
Texas. ${ }^{82}$ Here it has been held that a rule requiring vaccination by scarification was not unreasonable on the ground it gave preference to a particular school of medicine. ${ }^{83}$ In a Pennsylvania case, where the statute required vaccination as a condition precedent to school attendance, the court, in considering the intent of the legislature, stated that the obvious intent was to require "inoculation with the virus of cowpox for the purpose of communicating that disease as a prophylactic against smallpox. It indicates an operation, and not a result." ${ }^{84}$

Where parents have refused to have their children vaccinated as required by statute and/or a rule of the school board or board of health, and the children have been refused admission, the question of whether or not the parents may be prosecuted for violating the compulsory education law has sometimes arisen. On the question of the parents' liability under such circumstances, the courts are not in agreement. It appears that in those states where the statute permits or requires vaccination as a prerequisite to attendance, courts are likely to hold that a parent whose child is excluded because the parent refuses to have him vaccinated will be guilty of violating a compulsory education law. ${ }^{85}$ In commenting on this matter, a Massachusetts court said: ${ }^{86}$ "The statutory obligation to cause children to attend school involves an obligation to put them into condition to attend, and cannot be escaped by neglect to qualify them for attendance." This, it would seem, constitutes a sound principle of law. There appears to be, however, at least one case on the other side. In Ohio it has been held that a parent was not guilty, under similar circumstances. ${ }^{87}$ Where, however, a board requires vaccination because of the existence of an epidemic, a Missouri court has held that a parent could not be prosecuted when he failed to have his child vaccinated and the child was excluded, on the ground that the compulsory education statute and the statute giving the board the authority to make all needful rules, must be considered together. ${ }^{88}$ This case is to be distinguished from those previously cited, because here exclusion was temporary, i.e., for the period of the existence of the epidemic only. In the others, exclusion was permanent, unless the child was later vaccinated.

\section{$\mathrm{V}$}

Another aspect of the problem of pupil attendance involves the question of requiring resident pupils to pay tuition and/or fees as a condition precedent to school

${ }^{82}$ Abney v. Fox, 250 S.W. 2ro (Tex. Civ. App. 1923); McSween v. Board of School Trustees of City of Ft. Worth, 60 Tex. Civ. App. 270, I29 S.W. 206 (I910).

${ }^{83}$ McSween v. Board of School Trustees of City of Ft. Worth, 6o Tex. Civ. App. 27o, 129 S.W. 206 (Igro).

B4 Lee v. Marsh, 230 Pa. 35I, 357, 79 Atl. 564, 566 (I9II).

${ }^{85}$ Anderson v. State, 84 Ga. App. 259, 65 S.E.2d 848 (x95r); Commonwealth v. Childs, 299 Mass. 367 , I2 N.E.2d 814 (1938); Commonwealth v. Green, 268 Mass. 585, 168 N.E. Iox (1929); State v. Drew, 89 N.H. 54, I92 Atl. 629 (I937); In re Whitmore, 47 N.Y.S.2d 143 (Dom. Rel. Ct. 1944); People v. Ekerold, 2II N.Y. 386, ro5 N.E. 670 (I9I4); People v. Mcllwain, I5I N.Y. Supp. 366 (Co. Ct. I915); Commonwealth v. Butler, $76 \mathrm{~Pa}$. Super. II3 (I92I); In re Marsh, I40 Pa. Super. 472, I4 A.2d 368 (r940).

${ }^{88}$ Commonwealth v. Childs, 299 Mass. 367, I2 N.E.2d 814, 815 (1938).

${ }^{87}$ State v. Turney, 3 I Ohio Cir. Ct. R. 222 (1909).

${ }^{88}$ State ex rel. O'Bannon v. Cole, 220 Mo. 697, IIg S.W. 424 (I909). 
attendance. In some cases statutes have been enacted requiring such payment. In other cases, local school boards have attempted their collection in the absence of statute. In general, the courts are agreed that a statute requiring the payment of any fees is unconstitutional, where the constitution requires the legislature to maintain a system of free public schools. ${ }^{89}$ While recognizing this rule, it is interesting to note that a South Carolina court approved an exception to it in $1901 . .^{90}$ It held that the legislature had never set up a system of free schools such as was contemplated by the framers of the I 868 constitution, which provided for such a system, apparently, but did not make its creation mandatory because it set no time limit. It merely provided that such a system should be set up as soon as practicable. The entire scheme, in Igor, was still speculative and tentative. Consequently, the court held that there was nothing to prohibit the legislature from adopting some other scheme -one authorizing the payment of tuition fees-until such time as it found it practicable to set up the scheme contemplated by the constitution.

Where the school board passes a rule requiring the payment of tuition by resident pupils, the courts are also generally agreed that the rule is illegal if the constitution or legislation requires the mantenance of a free public school system. ${ }^{91}$ A Missouri court has also ruled that a school board had no right to charge tuition, even though the purpose of charging the fee was to recover money which board members had, individually, put up to buy equipment to start a two-year high school. ${ }^{22}$ In Kentucky, however, in a somewhat different kind of case, the court approved the charging of a tuition fee. Here, the teacher, by contract, was required to teach the common branches. When a parent demanded that his child be taught the higher branches, the teacher, with the board's permission, required the payment of a tuition fee, and the court approved. ${ }^{93}$

It has also been held that a school board cannot charge a registration fee, ${ }^{94}$ or a matriculation fee, ${ }^{95}$ both of which are in the nature of a charge for tuition. In Alabama, on the other hand, it has been held that a school board may pass a rule requiring the payment of matriculation or incidental fees. ${ }^{96}$ In this state, apparently, there is no constitutional requirement to the effect that the legislature shall main-

${ }^{80}$ Special School District No. 65, Logan County v. Bangs, I44 Ark. 34, 221 S.W. I060 (I920); Irvin v. Gregory, 86 Ga. 605, I3 S.E. I20 (189I); Holler v. Rock Hill School District, 6o S.C. $4 \mathrm{I}, 3^{8}$ S.E. 220 (rgor).

${ }^{00}$ Holler v. Rock Hill School District, 60 S.C. 4 I, 38 S.E. 220 (I90I).

${ }^{91}$ Bryant v. Whisenant, I67 Ala. 325,52 So. 525 (Igro); Roberson v. Oliver, I89 Ala. 82,66 So. 645 (1914); Brewer v. Ray, 149 Ga. 596, Ior S.E. 667 (1919); People v. Moore, 240 Ill. 408, 88 N.E. 979 (rgog).

${ }^{22}$ State ex rel. Roberts v. Wilson, 22I Mo. App. 9, 297 S.W. 4 I9 (1927).

${ }^{03}$ Major v. Cayce, $98 \mathrm{Ky} \cdot 357,33$ S.W. 93 (I895).

94 Dowell v. School District No. I, 220 Ark. 828, 250 S.W.2d 127 (1952).

${ }^{05}$ Brewer v. Ray, $x 49$ Ga. 596, IoI S.E. 667 (I9x9); Brinson v. Jackson, $x 68$ Ga. 353,148 S.E. 96 (1929); Claxton v. Stanford, I60 Ga. 752, 128 S.E. 887 (1925); Peak v. Board of Education of Cuthbert, I77 Ga. 476, 170 S.E. 488 (I933); Wilson v. Stanford, 133 Ga. 483, 66 S.E. 258 (I909).

${ }^{D 0}$ Bryant v. Whisenant, I67 Ala. 325, 52 So. 525 (I910); Kennedy v. County Board of Education, 2x4 Ala. 349, I07 So. 907 (I926); Roberson v. Oliver, I89 Ala. 82, 66 So. 645 (I9I4); Roberts v. Bright, 222 Ala. 677, 133 So. 907 (I93I); Ryan v. Sawyer, 95 Ala. 69, 7o So. 652 (19I6); Vincent v. County Board of Education of Talladega County, 222 Ala. 2I6, I3I So. 893 (I93I). 
tain a system of free schools. Instead, the constitution requires a "liberal system." In commenting on this, one court said: ${ }^{.7}$

This means that the schools shall be liberally maintained, and that they should be open to common and general use. But details of management involving charges such as are involved in this appeal [matriculation fee as well as a reasonable fee for library, laboratory and shop] may be left to the school trustees in charge.

While approving such fees, the courts of Alabama have, however, refused to approve a tuition fee. ${ }^{98}$ Also, the Alabama courts have refused to permit the use of incidental fees for the purpose of supplementing teachers' salaries, ${ }^{99}$ and have even held a teacher liable in damages for expelling a child who refused to pay such a fee, although the teacher acted under the direction of the board. ${ }^{100}$

In South Carolina and Missouri, on the other hand, the courts have held that a resolution of the board requiring the payment of an incidental fee was illegal.101 In the South Carolina case, the purpose of the fee was to raise money to pay for heating, seats, and an addition to the building. The court ruled that if the right to charge such a fee existed there would be no limit to the amount a board might charge:

It must be remembered that what has been said regarding the payment of tuition and fees applies only to pupils resident in the district. Frequently, some peculiar situations arise with reference to the payment of tuition by non-resident pupils. In Illinois a law authorized the school board of a school district that did not maintain a high school, to pay the tuition of those pupils, attending high school in another district, whose parents could not afford to do so. The court held the law obnoxious on the ground that if tuition was to be free to some, it must be free to all, since within a school district all children must be treated alike. ${ }^{102}$ Again, in Iowa a law provided that pupils residing in a district that did not maintain a high school might attend any high school that would receive them and that the home district would pay the tuition, not to exceed $\$ 8$ per month. When one district, whose per-pupil cost amounted to $\$ 15$ per month, attempted to collect from parents of non-resident pupils $\$ 7$ per month additional for tuition-the difference between the actual cost and the amount paid by the home district-an action was brought to restrain it from so doing. ${ }^{103}$ The court held that the board's action in charging this tuition fee was justified, because it was under no legal compunction to accept the non-resident pupils.

In a somewhat similar case, where a school district attempted to collect the differ-

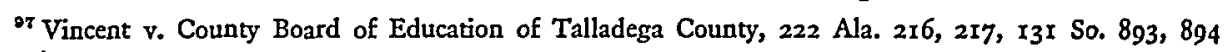
(I93I).

${ }_{98}$ Bryant v. Whisenant, $x 67$ Ala. 325, 52 So. 525 (1910).

${ }^{-90}$ Hughes v. Outlaw, I97 Ala. 452 , 73 So. I6 (I916); Williams v. Smith, I92 Ala. 428, 68 So. 323

(I9I5).

${ }_{100}$ Williams v. Smith, I92 Ala. 428,68 So. 323 (I915).

${ }^{101}$ State ex rel. Burnett v. School District of City of Jefferson, 335 Mo. 803, 74 S.W.2d 30 (1934);

Young v. Trustees of Fountain Inn Graded School, 64 S.C. 13I, 4 I S.E. 824 (1902).

${ }^{103}$ People v. Moore, 240 Ill. 408, 88 N.E. 979 (rgog).

${ }^{103}$ Chambers v. Everett, I9x Iowa 49, I8I N.W. 867 (I92x). 
ence between the cost of a child's education and what it received from the local district plus what it got in equalization funds from the state, a Missouri court ruled against the district. It held that the district could not make such a tuition charge for a non-resident pupil, but, on the other hand, that it need not accept the pupil. ${ }^{104}$

\section{VI}

It is a general principle, agreed to by most courts, that schools are maintained only-or at least primarily-for pupils resident of the district in which the school is located ${ }^{105}$ and that pupils residing in the district must be admitted free of tuition. ${ }^{106}$ The rule is different, of course, with respect to non-resident pupils. The distinction between resident and non-resident pupils is often not clear, and courts are frequently asked to rule on the right of a district to charge a particular pupil or pupils tuition. Most of such cases grow out of situations involving one of the following questions: ( $\mathrm{x}$ ) the question of the place of residence of the parents, (2) the question of the right of a child who resides apart from his parents to attend school in the district in which he resides, and (3) the question of the right of a child who resides in an orphans' home or other charitable institution to attend school in the district in which the institution is located.

In general, the courts hold that the residence, for school purposes, of an unmarried child of school age is that of the parents or guardian and cannot be changed by the minor except under unusual circumstances. ${ }^{107}$ The real difficulty frequently arises in determining what constitutes "residence" as used in statutes. In a very few cases, courts have held that "residence" and "domicile" are synonymous terms. Generally, however, they take a more liberal view of the matter and hold that residence for school purposes does not mean "legal domicile in the technical and narrow sense of residence of a person for purpose of taxation or suffrage."108

In certain cases where a family's residence is in a different school district than its domicile, the question of where the children may attend school free of tuition becomes exceedingly important. In some places, particularly at an earlier date, apparently it was not unusual for parents with children of school age to maintain a more or less temporary residence, apart from their domicile, in order that their children might take advantage of better educational opportunities. Where such is the case, courts are generally agreed that if the parents merely rent a room for the children or arrange for them to board in a school district, and if they return to the home

${ }^{104}$ State ex rel. Burnett v. School District of City of Jefferson 335 Mo. 803, 74 S.W.2d 30 (r934).

106 See pp. 24-25, sipra.

100 See pp. 36-38, stupra.

${ }^{107}$ Smith v. Binford, 44 Idaho 244,256 Pac. 366 (1927); Board of Education v. McCaskill, 212 Ill. App. I38 (r918); People v. Board of Education of School District No. 36, Edwards County, 206 Ill. App. 381 (1917); State ex rel. Flaughter v. Rogers, 226 Ind. 32, 77 N.E.2d 594 (1948); Wheeler r. Burrow, 18 Ind. 14 (1862); Salem Independent School District v. Kiel, 206 Iowa 967, 221 N.W. 519 (1928); Suizen v. School District No. 36 of City of Lecompton, I44 Kan. 648, 62 P.2d 880 (1937); Crain v. Walker, 222 Ky. 828, 2 S.W.2d 654 (1928); School District of Barnard v. Matherly, 90 Mo. App. 403 (1901); Anderson v. Breitbarth, 62 N.D. 709, 245 N.W. 483 (1933). (1950).

Turner v. City Board of Education of City of Mayfield, 313 Ky. 383, 386, 23I S.W.2d 27, 29 
of the parents over the week-ends, they do not have a residence in the district within the meaning of the law..$^{109}$ Where, however, the residence of the entire family is changed, but the domicile remains in the original district where the father continues to spend most of his time, the situation is somewhat different. Nevertheless, some courts have held the children not entitled to attend the schools of the "new" district tuition-free, as they remain, in reality, residents of the district in which they have their domicile. In other words, they have held "domicile" and "residence" synonymous. They have based their ruling on the fact that domicile and intention are determinative of the fact. In short, they have held that where a new residence is maintained for the sole purpose of attending school, children are not entitled to free tuition. ${ }^{110}$ Where, however, the entire family removes to a "new" district for purposes other than that of enrolling the children in the schools of that district, courts have held differently, even though the domicile remained unchanged. Thus, where a family moved in order to make it more convenient for the father to follow his occupation or conduct his business, even though he intended to return at some future time, courts have approved the attendance of the children in the schools of the new district, tuition-free. ${ }^{111}$ One of the most interesting cases of this type comes from Nebraska. Here, the statute provided that a child should attend the schools of the district in which the parents "live." When a newly elected Governor and State Superintendent of Public Instruction took office and moved, temporarily, to Lincoln, they attempted to enter their children in the public schools, but admission was denied. In a mandamus action to compel the board to admit them, the court ruled in favor of the Governor and Superintendent, although it recognized that they were but temporary residents of Lincoln and retained their legal residences elsewhere. ${ }^{112}$

What has been said, of course, applies to the unemancipated minor. If the parent emancipates the minor, then, of course, the residence of the minor, regardless of the purpose for which he maintains it, becomes his residence for school purposes. In Wisconsin a r6-year old boy was desirous of obtaining a high school education, but his father was unable to give him the financial assistance necessary. He agreed to emancipate the boy and.permit him to earn his own livelihood and be his own master. The boy then went to Richland Center, with the purpose of making that his home, earning his own living, and going to high school. He had no intention of returning to his father's home. When the question of the district's authority to charge him tuition was raised, it was held that he was not required to pay, because

\footnotetext{
${ }^{100}$ Inhabitants of Haverhill v. Gale, 103 Mass. 104 (1869); State ex rel. School District No. I, Niobara County v. School District No. 12, Niobara County, 45 Wyo. 365, 18 P.2d roro (1933).

${ }^{110}$ Sulzen v. School District No. 36 of City of Lecompton, 144 Kan. 648, 62 P.2d 880 (1937); State v. School District of City of Superior, 55 Neb. 317,75 N.W. 855 (1898); Board of Education of Union Free School District No. 2, Town of Trenton v. Crill, I49 App. Div. 407, 134 N.Y. Supp. 31 (4th Dep't IgI2).

${ }^{111}$ School District No. I Fractional of Mancelona Township v. School District No. I of Custer Township, 236 Mich. 677, 2II N.W. 60 (1927); Northern v. McCaw, I8g Mo. App. 362, 175 S.W. 317 (1915); State v. Selleck, 76 Neb. 747, ro7 N.W. I022 (1906).

${ }^{113}$ State v. Selleck, 76 Neb. 747, x07 N.W. 1022 (1906).
} 
he was a resident of the district. He lived in the district and he lived by toil which came first in his life. School came second. ${ }^{113}$

While it is a general rule that children can attend school, free, in the district in which they live, the question has been raised as to the proper district which one might attend when the house in which he lives is located on the boundary line between two districts. In Kentucky, where this question faced the court, it held that under such circumstances the child properly resided in the district in which the major part of the house was located. ${ }^{114}$

In those cases where a pupil lives or resides apart from his parents, a somewhat different question is involved. Here, the question is whether the residence of the child, for school purposes, is in the district of the family's domicile or in the district where the child is actually residing. In a few cases it has been held that the child's residence is the domicile of the parents or guardian regardless of his reason for living apart from them. ${ }^{115}$

While, as has been said, some courts have held that a child's residence is that of the parents, and that the child cannot obtain another, the best rule, it would appear, and the one most commonly followed by the courts, is that if a child is living apart from his parents or guardian, he may attend school, free, in the district in which he actually makes his home, providing he is living in the district for some purpose other than merely that of taking advantage of its educational opportunities. ${ }^{116}$ Needless to say, the application of this rule could make for some injustice in the case of particular school districts. This appeared to be the main contention in a case that arose in Maine. Here, a boy, who was a ward of the state, was committed, by court proceedings, to the custody of the state board of children's guardians. The board placed the boy in the home of a Mrs. Whalen of Yarmouth-a town in which his parents had no legal residence. Because Mrs. Whalen was not his guardian, the question arose as to whether the boy had the right to attend the public schools free

${ }^{113}$ Kidd v. Joint School District No. 2, City of Richland Center and Town of Richland, r94 Wis. 253, 216 N.W. 499 (1928).

114 Turner v. City Board of Education of City of Mayfield, 313 Ky. 383, 23I S.W.2d 27 (I950).

${ }^{115}$ Wheeler v. Burrow, 18 Ind. I4 (1862); Board of Education of City of Winchester v. Foster, II6 Ky. 484, 76 S.W. 354 (I903); Binde v. Klinge, 30 Mo. App. 285 (I888); Mansfield Township Board of Education v. State Board of Education, Ior N.J.L. 474, r29 Atl. 765 (I925).

${ }^{210}$ Cline v. Knight, III Colo. 8, I37 P.2d 680 (r943); Fangman v. Moyers, 9o Colo. 308, 8 P.2d 762 (1932); Yale v. West Middle School District, 59 Conn. 489, 22 Atl. 295 (I890); Board of Education v. Lease, 64 Ill. App. 60 (1895); Dean v. Board of Education of School District No. 89, 386 Ill. 156, 53 N.E.2d 875 (1944); People v. Board of Education of School District No. 36, Edwards County, 206 Ill. App. 38r (r9I7); Mt. Hope School District v. Hendrickson, I97 Iowa I9I, 197 N.W. 47 (I924); Board of Trustees of Stanford Graded Common School District v. Powell, I45 Ky. 93, I40 S.W. 67 (IgII); Shaw v. Small, I24 Me. 36, I25 Atl. 496 (I924); State ex rel. Halbert v. Clymer, I64 Mo. App. 67I, 147 S.W. xI19 (1912); MeNish v. State ex rel. Dimick, 74 Neb. 26x, I04 N.W. I86 (1905); Martins v. School District No. 30 of Cuming County, IoI Neb. 258, I62 N.W. 63I (I9I7); Mizner v. School District No. II of Sherman County, 2 Neb. (Unof.) 238, 96 N.W. I28 (Igor), $a f f^{\prime} d, 2$ Neb. (Unof.) 242, 96 N.W. I006 (xg03); People ex rel. Brooklyn Children's Aid Society v. Hendrickson, I25 App. Div. 256, 109 N.Y. Supp. 403 (2d Dep't 1908), affd, I96 N.Y. 55r, 90 N.E. II63 (I909); Anderson v. Breitbarth, 62 N.D. 709, 245 N.W. 483 (I933); Board of Education of City of El Reno v. Hobbs, 8 Okla. 293, 56 Pac. 1052 (1899); Confluence Borough School District v. Ursina Borough School District, 88 Pa. Super. 299 (r926); State v. Thayer, 74 Wis. 48, 41 N.W. 10r4 (1889). 
of tuition. The court, in holding that he did, ruled that the "statutes relating to public schools should receive a liberal construction in aid of their dominant purpose which is universal elementary education."117 To the contention that the placing of some 23 wards of the state in the town of Yarmouth, by the state board of children's guardians, constituted a burden upon the town, the court pointed out that there was merit to this contention, but that only the legislature and not the courts could grant the necessary relief.

In a Pennsylvania case, however, a court ruled differently. ${ }^{118}$ Here, in the case of a child who had been committed, as a result of court proceedings, to the care of another, it held that the child had no right to attend school free of tuition in the district in which the person to whom he was committed lived. The court reasoned that, in this type of case, an involuntary relationship existed between the child and guardian, as far as the child was concerned. It also characterized this as a business relationship assumed by the guardian for the purpose of making a living. As a result, it reasoned that such homes, to which children were committed, were only temporary places for the detention of the children. Consequently, it ruled that the presence in the district of a dependent and incorrigible child did not constitute a residence.

It must not be forgotten, however, that courts are generally agreed that children residing apart from their parents for the sole, or primary, purpose of attending school in the district to which they have moved are not entitled to free tuition. ${ }^{110}$

A still different situation prevails in the case of a child who resides in an orphans' home or some other type of charitable institution. Then the question of the right of the child to attend school in the district in which the home or institution is located comes to the forefront. In most of such cases the courts have held that the child has this right, providing he is under the control of the home's authorities and is residing in the home for purposes other than that of attending school. ${ }^{120}$ In one of the earliest cases of this type, in which a New Hampshire court ruled that children dwelling in a poorhouse were entitled to attend schools in the district in which

${ }^{127}$ Shaw v. Small, 124 Me. 36, 40, 125 Atl. 496, 498 (1924).

${ }^{118}$ Black v. Graham, 238 Pa. 38x, 86 Atl. 266 (1913).

${ }^{118}$ People v. Board of Education, 26 Ill. App. 476 (1888); Wheeler v. Burrow, 18 Ind. 14 (1862); Mt. Hope School District v. Hendrickson, I97 Iowa I91, 197 N.W. 47 (1924); School District No. $x$ v. Brogdon, 23 N.H. (3 Fost.) 507 (185x); Mansfield Township Board of Education v. Statc Board of Education, ror N.J.L.474, I29 Atl. 765 (I925); Horowitz v. Board of Education of City of Yonkers, 217 App. Div. 233, 216 N.Y. Supp. 646 (2d Dep't r926); State v. Board of Education of City of Eau Claire, 96 Wis. 95, 7x N.W. 123 (1897).

${ }^{120}$ Ashley v. Board of Education, 275 Ill. 274, II4 N.E. 20 (19I6); Logsdon v. Jones, 3 I I Ill. 425, 143 N.E. 56 (1924); Salem Independent School District v. Kiel, 206 Iowa 967, 221 N.W. 5 I9 (I928); School Township 76 of Muscatine County v. Nicholson, 227 Iowa 290, 288 N.W. I23 (1939); Mariadahl Children's Home v. Bellegarde School District No. 23, I63 Kan. 49, 180 P.2d 612 (I947); Crain v. Walker, $222 \mathrm{Ky} .828,2$ S.W.2d 654 (1928); Jefferson County Board of Education v. Goheen, $306 \mathrm{Ky}$. 439, 207 S.W.2d 567 (1947); State ex rel. Board of Christian Service of Lutheran Minnesota Conference v. School Board of Consolidated School District No. 3, 206 Minn. 63, 287 N.W. 625 (I939); School District No. 2 v. Pollard, 55 N.H. 503 (1875); State ex rel. Johnson v. Cotton, 67 S.D. 63,289 N.W. 7 (1939); Grande Lodge I.O.O.F., of West Virginia v. Board of Education of Independent School District of Elkins, 9o W. Va. 8, r ro S.E. 440 (I922). 
the poorhouse was located, the language of the court is especially interesting. It said: $:^{121}$

.. . charity will continue to dispense not bread alone, but, without distinction of person, the blessings of moral culture and the means of mental illumination, even as God pours his sunbeams alike upon the just and unjust.

In spite of this general rule, the decisions of some courts have been to the contrary. ${ }^{122}$ The exceptions to the general rule are, on the whole, more apparent than real. For example, two of the Ohio cases appear to have been decided in terms of a statute that made the school district in which a child had formerly resided liable for his tuition when he became an inmate of a home of the sort involved there. ${ }^{123}$ Also, one of the Pennsylvania cases involved an interpretation of two statutes. ${ }^{124}$ One provided that the residence of a child who has no parents or guardian shall be considered to be in the district in which the person who sustains a parental relationship toward the child resides. Another provided that a board of school directors of a district in which an orphans' home was located could permit children who were inmates of the home, but who were not residents, to attend school with or without the payment of tuition. It also provided that if tuition was charged it was to be paid for by the district from which the child had come.

Again, in one Pennsylvania and in one Michigan case, at least one decisive factor influencing the court's opinion was the fact that the charitable institution or home was created in part for the purpose of educating the children admitted. ${ }^{125}$ It should also be pointed out that the Vermont case has a slightly different angle than most of the other cases. ${ }^{126}$ Here, the court held that where a town supported its pauper children in a poorhouse operated jointly with other towns, the education of the child remained the responsibility of the town from which the child came and did not shift to the town in which the poorhouse was located.

If these cases, just commented upon, are ignored, it is apparent that the exceptions to the general rule-minor inmates of charitable institutions are entitled to attend schools tuition-free in the districts in which the institutions are located-are comparatively few in number.

${ }^{121}$ School District No. 2 v. Pollard, 55 N.H. 503, 507 (1875).

${ }^{122}$ Child Welfare Society of Flint v. Kennedy School District, 220 Mich. 290, 189 N.W. 1002 (1922); Lake Farm v. District Board of School District No. 2, Kalamazoo Township, I79 Mich. I71, 146 N.W. I15 (1914); State ex rel. Methodist Children's Home Association of Worthington v. Board of Education of Worthington Village School District of Franklin County, t05 Ohio St. 438, I38 N.E. 865 (I922); State v. Directors of School District No. $x 4$, 1o Ohio St. 448 (I859); State v. Sherman, I04 Ohio St. 317 , I35 N.E. 625 (I922); Commonwealth v. Directors of Upper Swatara School District, I64 Pa. 603, 30 Atl. 507 (1894); School District of Borough of Ben Avon v. School District of Pittsburgh, 77 Pa. Super. 75 (1921); Sheldon Poor-House Asssociation v. Town of Sheldon, 72 Vt. 126, 47 Atl. 542 (1900).

${ }^{133}$ State ex rel. Methodist Children's Home Association of Worthington v. Board of Education of Worthington Village School District of Franklin County, I05 Ohio St. 438, I38 N.E. 865 (I922); State v. Sherman, 104 Ohio St. 3 I7, 135 N.E. 625 (1922).

${ }_{124}$ School District of Borough of Ben Avon v. School District of Pittsburgh, 77 Pa. Super. 75 (I921).

${ }^{125}$ Lake Farm v. District Board of School District No. 2, Kalamazoo Township, 179 Mich. 171, 146 N.W. 115 (1914); Commonwealth v. Directors of Upper Swatara School District, 164 Pa. 603, 30 Atl. 507 (1894).

${ }^{120}$ Sheldon Poor-House Association v. Town of Sheldon, 72 Vt. 126, 47 Atl. 542 (r9o0). 
One other aspect of the problem of school attendance concerns the right of children to elect to attend school tuition-free, in the district in which the parents own property and pay taxes, rather than in the district of residence. In the absence of a statute to the contrary, a child cannot attend school tuition-free, in a district in which the parent pays taxes, unless it is the district in which he resides. ${ }^{127}$ Where there is a statute concerning this matter, it is, of course, decisive. In South Carolina the statute provided that a parent could elect to send his children to a district adjoining the one in which he resided if he owned property and paid taxes there. In a recent case the court held this law was not unconstitutional and did not unlawfully discriminate against persons not holding property in adjoining districts. Furthermore, it held that the fact that a parent acquired property in an adjoining district for the sole purpose of enabling him to send his children to school in that district was immaterial. Also, it held of no consequence the facts that the property was of little value and that the taxes amounted to but three or four dollars per year. ${ }^{128}$ In Kansas the legislature had passed a similar statute. Later, it passed another statute that gave rural high school boards the authority to collect tuition from non-resident pupils. In an action involving the right of a parent to elect to send his children to school, tuition-free, to a district in which he was a property owner, but not a resident, it was held that he could not on the ground that the latter statute controlled and so acted to repeal the former one. ${ }^{129}$

${ }^{127}$ Reed v. Mason County Board of Education, 220 Ky. 489, 295 S.W. 436 (r927); Cape Girardeau School District No. 63 of Cape Girardeau County v. Frye, 225 S.W.2d 484 (Mo. 1949); Logan City School District v. Kowallis, 94 Utah 342, 77 P.2d 348 (r938).

${ }_{128}$ Moseley v. Welch, 218 S.C. 242, 62 S.E.2d 313 (1950).

${ }^{120}$ Burling v. Trembley, Ir3 Kan. 746, 216 Pac. 285 (1923). 